\title{
IMPLEMENTATION OF TPS LEARNING MODELS WITH PROBLEM POSING TO TRAIN CREATIVE THINKING ON ACID-BASE
}

\author{
Wisma Imelda Setyowati ${ }^{1}$ dan Rusmini ${ }^{2}$ \\ 1, 2 Pendidikan Kimia, Universitas Negeri Surabaya \\ Jl. Ketintang, Ketintang, Gayungan, Kota Surabaya, Jawa Timur 60231 \\ ${ }^{1}$ Email: wismasetyowati16030194049@mhs.unesa.ac.id \\ ${ }^{2}$ Email: rusmini@unesa.ac.id
}

\begin{abstract}
The research aims to be aware of the implementation of the TPS learning model with problem posing strategies on acid-base, student activity, creative thinking skills, completeness of learning outcomes, and responses of the learning model used. Use one group pretest-posttest research design and was applied to 54 high school students in class XI. The average percentage obtained by the feasibility of the learning model to $91.67 \%$ at the first meeting and to $98.60 \%$ at second meeting which both of them fall into the excellent category. The relevant activities result at the first meeting to $94,69 \%$ and irrelevant by $5,31 \%$ while activities of relevant at second meeting to $93,09 \%$ and irrelevant by $6,91 \%$, creative thinking skills increased by a percentage of $40.74 \%$ for the high category, $44.44 \%$ medium category, and $14.82 \%$ low category, for classical completeness learning outcomes by $88.89 \%$, and students' responses were $95.60 \%$ positive while $4.40 \%$ for negative responses.
\end{abstract}

Keyword: Acid base, creative thinking skill, TPS learning model, problem posing.

\section{INTRODUCTION}

One of the most important in the life cycle was education because through education people would get many benefits that be used to solve the problems in society, nation, and state. Especially in the modern, global, and millennial times that would receive the industrial era 4.0, then the nation's next generation must have a competitive and productive soul. So needed for a media, a container, and ways to shape the desired generation.

Chemistry subjects in high school include parts of science that learn the composition, structure, characteristics, and changes in the material. Thus the chemistry learning needs to be related between skills and reasoning. Chemistry was a required subject in the Mathematics and Natural Sciences major in senior high school. One of sub matter in acid base was an indicator and calculation of the initial concept of $\mathrm{pH}$ in acid base solutions. Both sub materials were the basis of the deeper concept of acid base. Acid base was often related to the facts that exist around the environment (Permendikbud, 2018). 
The demand for learning in the 21 st century, the skills that must be demonstrated was thinking, and being creative, collaborative, productive, independent, communicative, and critical to solve a problem (Kemendikbud, 2016).

The highest level of thinking after remember, basic, and critical thinking was creative thinking (Apino \& Retnawati, 2017). In creative thinking, someone would be able to create new ideas or original products, new works, or modifications from previous things, and most are different from before (Panjaitan \& Edy, 2017). So the benefits of creative thinking were new knowledge added and the creation of solutions to solve problems (Marliani, 2015).

Based on data in the field that the mastery of students' creative thinking was still lacking and minimal, this was due to the passive activity in learning. Besides, it was also proven by the test results of creative thinking skills on aspects fluency to $6,64 \%$, flexibility $6,76 \%$, and originality about $6,58 \%$ which answered by correct and accordance by topic and the results of the pre-research questionnaire that about $71,88 \%$ students state it was difficult to study chemistry.

This is also supported by other studies at SMA Negeri 1 Pacet that nothing of practicum activities caused students difficulties in studying acid-base material about $63,16 \%$. Acid base theories that were described by determination the characteristic of the solution and then its $\mathrm{pH}$ calculation were the basic competencies of acid-base material. So students were demanded to did a practicum to determine the properties of solution that used in the calculation of $\mathrm{pH}$ (Mu'minin dan Utiya, 2014).

Creative thinking skills be able to train by use acid base material on BC 3.10 Explain the concepts of acids and bases also their strength and ionization equilibrium in solution and $\mathrm{BC} 4.10$ Analyze the $\mathrm{pH}$ range of several indicators extracted by natural ingredients through experiments (Permendikbud, 2018). For the teaching and learning process and competencies to be reached, it must be done systematically and structurally. The teaching and learning process can be applied by a learning model.

The activities in the teaching and learning process can be interesting when students learn with their peers or in groups. Because through the groups, students would be discussed by each other to find and understand the difficulties of a concept so that becomes easier (Abidin, Siti, dan Bachtiar, 2019). In addition through group learning, that was can be more effective (Veldman, $\mathrm{dkk}, 2020$ ). 
Group learning is able to do by applying cooperative learning models. The use of various teaching methods which when forming groups the students contribute to each other to learn the material received. Think-pair-share (TPS) type cooperative learning models appropriate for group lessons. Stages of learning models included were thinking, pairing, dan sharing (Arends, 2013; Irwansyah, I Ketut Muhardika, dan Bambang S., 2016).

TPS learning model presents a learning process that originated by doing, finding, and sharing conclusions (Jannah \& Firman, 2019). The method used was able to make students feel of the learning process conditions that were fun, active, creative, and innovative by assuming discussion in control of established regulations (Hetika, Ida, dan Yeni, 2017; Handayani \& Yuli Yanti, 2017; Sumarya, 2020). In addition, the emphasized by this learning model lies in the importance of social relations within a group to build knowledge (Emerson, Linda, and KimMarie, 2016; Arki, Army, dan Iwan, 2017).

In addition, problem posing strategy used by this research. Problem posing was an approach or strategy that emphasizes the formation or submission of questions obtained by information or situation. This activity leads to a critical and creative attitude. Creative attitude is a person's ability to be creative (Suriasa, 2018). The other advantage that was students can gain knowledge by analyzing a problem (Sriwenda, et al, 2013). With these advantages, the problem posing strategy that was useful to train creative thinking skills by group methods was expected to be implemented effectively.

The linkage of the TPS learning model with the problem posing strategy can be seen from the stages they have. At the pre solution posing stage, students were trained in linking the information they obtained by the material they have learned. Then in the within solution posing stage, was trained to formulate sub-questions to solve a problem and post solution posing, was trained to produce questions similar to those given.

So that when adjusted by the TPS syntax, the pre solution posing stage can be done in the first phase (the motivating part of students), within solution posing and post solution posing stage can be done in the second phase (raised problem/thinking), and the last in the sharing stage, students be able to disseminate or communicate the results of their discussions so that other students can answer the questions that have been made (Lie, 2007).

Based on Bloom's revised taxonomy, the cognitive realm belonging to the creative thinking ability was C6: creating (Anderson dan Krathwohl, 2001). Creative thinking skills 
included by many indicators that were flexibility of thinking, fluency of thinking, originality, and elaboration (Marliani, 2015; Muharwati, 2014; La Moma. 2015; Alghafri $\&$ Ismail, 2014). However, creative thinking skills that were trained by only 3 indicators, namely fluency of thinking, flexibility of thinking, and originality.

This research aims to determine the impact of applying the TPS learning model with problem posing strategies in practicing creative thinking skills and student learning outcomes.

\section{RESEARCH METHODS}

Learning models and strategies used to train creative thinking skills in this study include the type of applied research (implementation research). The design of this study followed by "one group pretest-posttest design" with the target 54 students in SMA Negeri 4 Sidoarjo class XI when the even semester.

$$
\mathrm{O}_{1} \mathrm{X} \mathrm{O}_{2}
$$

(Sugiyono, 2018)

This research was conducted on January 9-21, 2020 or during 2x meetings with a duration of $2 \times 45$ minutes for each meeting. After obtaining the desired data, researchers conducted data analysis including.

1. Lembar Observasi Analisis penerapan model pembelajaran

The formula for calculating implementation in each activity is:

Implementation $=\frac{\text { btained score }}{\text { score } \max } \times 4$

Then the results were analyzed using the criteria for managing learning.

Quality of Learning Implementation

$\%$ Implementation $=\frac{\text { observer } \text { average score }}{\text { score } \max } \times 100 \%$

When the teacher's expertise in implementing learning reaches $\geq 61 \%$ which means good or very good then the implementation of the learning was effective (Riduwan, 2015).

2. Analysis of Student Learning Activities

The percentage of activities during the learning process takes place every 3 minutes using a formula:

$\%$ Student activities $=\frac{\sum \text { frequency of student activities that appears }}{\sum \text { overall activity frequency }} \times 100 \%$

(Arifin, 2010) 


\section{Analysis of Creative Thinking Skills Assessment}

The analysis would be conducted on 3 aspects of creative thinking skills that were originality, fluency, and flexibility.

The formulation to determine the value of creative thinking skills was as follows.

The creative thinking aspects of students $=\frac{\text { observer average score }}{\text { score } \max } \times 100 \%$

Student creativity scores obtained were converted using the formula:

$$
\text { Score obtained }=\frac{\text { value obtained }}{25}
$$

(Permendikbud Nomor 104 Tahun 2014)

Creative thinking skills before and after conditioning the learning model was analyzed by calculating the difference between the average pretest and posttest scores (n-gain score), the formula:

$$
n \text {-gain }=\frac{\text { posttest score-pretest score }}{\text { score max }- \text { pretest score }}
$$

Based on the n-gain value of creative thinking skills will be grouped into several criteria including: 1) $\mathrm{g} \leq 0,30$ for low criteria, 2) $0,30 \leq \mathrm{g}<0,70$ for medium criteria, and 3) $\mathrm{g} \geq$ 0,70 for high criteria (Riduwan, 2015).

4. Analysis of Learning Outcomes Tests

Improved learning outcomes can be analyzed by the calculation of the difference in the average pretest and posttest scores. This calculation was to get the n-gain score data, it can also state the level of creative thinking skills as a result of the behavior being worked on. Following was the formula for calculating n-gain scores:

$$
n \text {-gain }=\frac{\text { posttest score-pretest score }}{\text { score } \max -\text { pretest score }}
$$

The value of learning outcomes can be calculated through the formula.

$$
\text { Learning outcomes score }=\frac{\sum \text { correct answers }}{\sum \text { total questions }} \times 4
$$

If the score of student learning outcomes reaches $\geq 2.67$ and gets the B-title, the learning outcomes can be said to be complete.

The percentage of classical completeness has the formula:

$$
\% \text { Classical completeness }=\frac{\text { amount of students who completed }}{\text { amount of all students }} \times 100 \%
$$

(Riduwan, 2015)

If you get score $\geq 75 \%$ then gets the B-title so classical completeness has been achieved. 


\section{Analysis of Student Responses}

The questionnaire response analysis was carried out by used how to change the frequency value into a percentage, the formula:

$\% \mathrm{P}=\frac{F}{N} \times 100 \%$

Explanation:

$\mathrm{P}=$ Answer from the response

$\mathrm{F}=$ Total students who answered "Yes"

$\mathrm{N}=$ Amount of respondent

(Riduwan, 2015)

If all students have a positive response or answer "Yes" $\geq 61 \%$ then the learning model with the strategies used can be said to be effective for the learning process.

\section{RESULTS AND DISCUSSION}

\section{The implementation of the TPS Cooperative Learning Model with the problem posing strategy}

In the introduction, there was Phase 1, conveyed objectives and motivated students. After the teacher checks the attendance of students, then gives the apperception of relevant material and has been studied to build students' initial knowledge. Apperception aims to relate previous lessons with lessons to be received. As a result, they would be realized their own knowledge in understanding the task was performed. When teaching new subject matter, the teacher must relate it by the experience around the environment of the student first according to needs to facilitate understanding (Nurhasnawati, 2004).

After that, students get motivated by teachers in the form of questions in daily life, then they must relate it to acid-base indicators. This motivation aims to stimulate them and play an active role in founding a concept of a given phenomenon. Because every knowledge uses an example of interaction with experience. One cannot construct knowledge without interacted with objects (Suprijono, 2012).

Furthermore, the teacher gives material that was discussed in each meeting and learning objectives that would be achieved. Submission of learning objectives plays a role so that students are aware of the achievements that must be carried out during the learning process in order to relevant to learning objectives that have been set (Trian M, 2016). At 
the introduction stage, the allocated time was 10 minutes, for the average percentage at the introduced stage was $87.50 \%$ at the first meeting and $97.88 \%$ for the second meeting.

In phase 2, the teacher was presenting information and the problem. The teacher presents the whole material briefly (Suprijono, 2012). Explanation of acid-base indicator material was given by the outline. Next submitted questions regarding learning, then from the information provided the teacher gives examples of how to make questions. The teacher must be given one or two sample questions and be accompanied by workmanship (Sitohang and Sahat, 2018).

The example given by the teacher was the first step in the problem posing strategy, was presolution posing. After that, the teacher gives examples of questions that almost similar to the previous ones and how to solve them. The activities carried out by the teacher was the second stage in the problem posing strategy, was within solution posing. So the average percentage in phase 2 was $87.50 \%$ in the first meeting and $100 \%$ for the second meeting.

Activities in phase 3, formed groups. By learning through groups, the role of peers was needed (Abidin, Siti, and Bachtiar, 2019). The teacher then distributes worksheet 1 which contained by acid base indicators when the first meeting and worksheet 2 about acid base $\mathrm{pH}$ at the second meeting. Then they would get and collected information by the phenomena that have been presented. This was in accordance with the dimensions of bloom's cognitive taxonomy process that was the $\mathrm{C} 2$ dimension, understanding. The process of understanding can be realized because of a question that encourages students to understand the phenomenon that was presented to be able to answer the question (Anderson and Krathwohl, 2001).

After that students work on the problem as exemplified. The questions was to be presented still in one topic but not completely the same as the previous example. So that when faced with a new problem was expected to train understand of the topics that have been studied (Sitohang and Sahat, 2018).

Furthermore, students work on the questions that have been presented in worksheet 1 and 2 where the type of questions was in accordance with the problem posing strategy, was postsolution posing. In this stage, the creative thinking ability can be trained because of filing a problem that has been made. When raising a problem, students compile questions from available information (Siswono, 2004). In addition, when raising a problem then 
different problems would be formed because the submission of different problems is related to creativity (Murtafiah, 2017; Sengul and Yasemin Katranci, 2015). Students were given 5-10 minutes to think about the answer independently. After that, they discuss the answers obtained by a group of friends for 10-15 minutes. In the process of making or formulating questions, it was one of the activities included in the C6 cognitive domain, that was the creation (Anderson and Krathwohl, 2001). The average percentage in phase 3 was $100 \%$ in the first and second meetings.

Activity in phase 4, helped the teamwork in the discussion. The teacher can assist in the form of instructions by encouraging students to remember the way of resolution that has been exemplified in phase 2 as a reference or reference in setting their own ways of solving problems (Suprijono, 2012). So the average percentage in phase 4 was $100 \%$ in the first and second meetings.

Phase 5, evaluation. Students present the results of the discussion with many 2-3 pairs of groups in turn. The aim was to test how understanding his knowledge of the material has been learned (Sekhah, 2011). Percentage of accomplishment that was equal to $100 \%$ at the first or second meeting.

Next was entered the closing phase, named phase 6, giving awards. The teacher reflects the learning outcomes and evaluated their activities by asking students. The aim was to clarify concepts developed by students so that the knowledge gained was meaningful and useful and as a correction or evaluation for the teacher's teaching procedures in the classroom. The teacher gives feedback or rewards for those who have actively participated. With this award, students would be more motivated and motivated to learn at the next meeting (Sanjaya, 2013). The percentage of the implementation at the first meeting was $87.50 \%$ and $93.75 \%$ for the second meeting.

In the descriptions, the conclusion was the syntax of the TPS type cooperative learning model with the problem posing strategy obtains very good categories. The success achieved cannot be separated by the activities of students who enthusiastically accompany all the learning processes. The following was the acquisition of a recapitulation the learning model implementation in Table 1. 
Table 1. The Results of the Recapitulation the TPS Type Cooperative Learning Syntax With Problem Posing Strategy

\begin{tabular}{|c|c|c|c|c|c|c|}
\hline \multirow[b]{2}{*}{$\begin{array}{l}\text { Learning } \\
\text { Activities }\end{array}$} & \multicolumn{3}{|c|}{ Meeting 1} & \multicolumn{3}{|c|}{ Meeting 2} \\
\hline & $\begin{array}{l}\text { Averag } \\
\text { e score }\end{array}$ & $\begin{array}{c}\text { Average \% } \\
\text { quality of } \\
\text { implement } \\
\text { ation } \\
\end{array}$ & $\begin{array}{c}\text { Catego } \\
\text { ry }\end{array}$ & $\begin{array}{l}\text { Averag } \\
\text { e score }\end{array}$ & $\begin{array}{c}\text { Average } \% \\
\text { quality of } \\
\text { implement } \\
\text { ation }\end{array}$ & $\begin{array}{c}\text { Catego } \\
\text { ry }\end{array}$ \\
\hline $\begin{array}{c}\text { Introduction } \\
\text { Phase } 1\end{array}$ & 3,5 & 87,50 & $\begin{array}{l}\text { Very } \\
\text { good }\end{array}$ & 3,9 & 97,88 & $\begin{array}{l}\text { Very } \\
\text { good }\end{array}$ \\
\hline Phase 2 & 3,5 & 87,50 & $\begin{array}{l}\text { Very } \\
\text { good }\end{array}$ & 4 & 100 & $\begin{array}{l}\text { Very } \\
\text { good }\end{array}$ \\
\hline Phase 3 & 4 & 100 & $\begin{array}{l}\text { Very } \\
\text { good }\end{array}$ & 4 & 100 & $\begin{array}{l}\text { Very } \\
\text { good }\end{array}$ \\
\hline Phase 4 & 4 & 100 & $\begin{array}{l}\text { Very } \\
\text { good }\end{array}$ & 4 & 100 & $\begin{array}{l}\text { Very } \\
\text { good }\end{array}$ \\
\hline Phase 5 & 3,5 & 87,50 & $\begin{array}{l}\text { Very } \\
\text { good }\end{array}$ & 4 & 100 & $\begin{array}{l}\text { Very } \\
\text { good }\end{array}$ \\
\hline $\begin{array}{l}\text { Closing } \\
\text { Phase } 6\end{array}$ & 3,5 & 87,50 & $\begin{array}{l}\text { Very } \\
\text { good }\end{array}$ & 3,75 & 93,75 & $\begin{array}{l}\text { Very } \\
\text { good }\end{array}$ \\
\hline
\end{tabular}

\section{Students Activities}

Activities that were observed consist of relevant and irrelevant activities. The activities to be observed were listed in the following Table 2.

Table 2. Data Observing of Student Activities

\begin{tabular}{|c|l|}
\hline No. & \multicolumn{1}{|c|}{ Observed Activities } \\
\hline 1. & Noticed the teacher explanation \\
2. & Expressed a question or answer \\
3. & Formed a group \\
4. & Read the phenomena available \\
5. & Produced a question based on the phenomenon \\
6. & Discussed by a group of friends \\
7. & Doing an experiment \\
8. & Observed the experiment \\
9. & Working on the questions in the worksheet \\
10. & Analyzed of experimental data \\
11. & Presented of group discussion results \\
12. & Refuted of presentation results \\
13. & Make a conclusion \\
14. & Doing irrelevant activities \\
\hline
\end{tabular}

The frequency of student activities would be observed by every 3 minutes during the learning process. Obtaining the results of observing activities can be observed in Figure 1. 


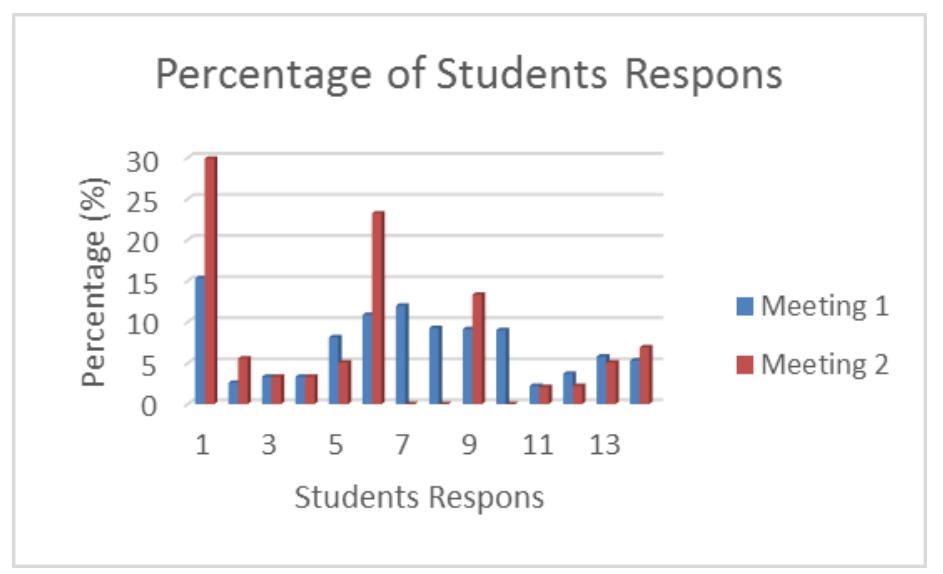

Figure 1. Percentage Diagram of Student Activity

The most stand out activity of students was paying attention to the teacher's explanation with a percentage of $15.31 \%$ for the first meeting and by $29.88 \%$ for the second meeting. The activity was most dominant because at the time of the initial explanation along with examples of work to solve the problem type problem posing takes place with considerable time.

At the first meeting, students often do irrelevant activities when practicum activities would be completed. At the second meeting, irrelevant activities were very visible when in phase 2 , when presenting information and raising problems. The percentage of activities that were not relevant at the first meeting was $5.30 \%$ and the second meeting was $6.91 \%$.

\section{Creative Thinking Skills}

The applied creative thinking skills consist of four indicators to be measured, that was flexibility, fluency, originality, and elaboration. However, in this research, only three indicators were used, including fluency, flexibility, and originality (Munandar, 2009; Muharwati, 2014; La Moma. 2015; Alghafri \& Ismail, 2014).

The pretest and posttest tests that would be tested contain a problem that was in the laboratory and phenomena based on authentic problems. When faced by these conditions, the students 'thoughts would be stimulated to think creatively and differently, so this was a facility to develop students' creativity. (Zuya, 2017).

At the below was the average percentage of pretest and posttest results in creative thinking skills shown in Figure 2. 


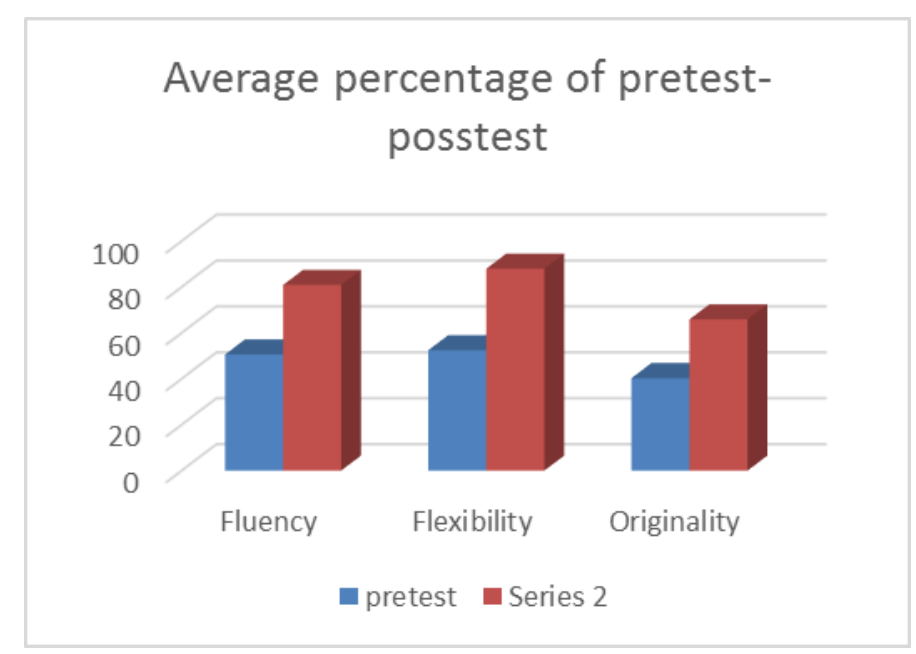

Figure 2. The average percentage of students' pretest and posttest scores in creative thinking skills

From Figure 2, it can be said that there appears to be an increase in the value of each indicator after learning was applied twice.

After calculating using the gain score the results were as many as 8 students included in the low criteria, 24 medium criteria and 22 high gain criteria. So it can be interpreted that the learning model and strategy implemented can train creative thinking skills on acid-base material as indicated by an increase in the posttest score with the score gain score.

TPS type cooperative learning model with problem posing strategy to practice creative thinking skills was strengthened by other research which states that when learning in groups it was easier to understand the material (Restu, 2018). This results in students being able to express various ideas to solve a problem. Because when making questions, students were eager to find the information needed so that a problem can be formed. So that students' creative thinking skills can be trained by activities such as finding ideas and analyzing answers.

\section{Knowledge Learning Outcomes}

The learning achievement test contains 10 multiple choice questions. This test was a knowledge test. To determine the impact of the application of this learning, a pretest and posttest were conducted. The aim of teaching was said to be achieved if there were differences experienced by students before and after participating in learning in various aspects (Suprijono, 2016). Data completeness learning outcomes can be seen in Figure 3. 


\section{$11 \%$}

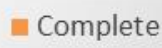

Not complete

$89 \%$

Figure 3. Data of Completeness Learning Outcomes

From Figure 3 as many as 6 students did not complete in carrying out the learning outcomes test of the realm of knowledge on acid-base material because the scores generated were below the KKM, while as many as 48 students had completed carrying out the learning outcomes test.

Classically the acquisition of learning outcomes amounted to $88.89 \%$ more than $75 \%$, so that the classical completeness that was expected to have been achieved. The cooperative learning model was an implementation of a constructivist approach in learning. So when meeting difficult concepts, students can more easily find and understand through discussion of problems in a group way (Abidin, Siti, and Bachtiar, 2019).

Thus, it can be concluded that the TPS type of cooperative learning model with a problem posing strategy can improve student learning outcomes in acid-base material. Judged by the success of students in answering questions during the test, where the average value generated was 81.67 .

\section{Students Respons}

Response assessment uses a questionnaire response sheet that was distributed to all students in the class. The aim was to find out their response to the learning model used so that it can be an evaluation for the model teacher. Percentage response data are listed in Table 3 below. 
Table 3. Student Results Questionnaire Results Data

\begin{tabular}{|c|c|c|c|c|c|}
\hline \multirow{2}{*}{ Questions } & \multicolumn{2}{|c|}{ Amount } & \multicolumn{3}{c|}{ Percentage (\%) } \\
\cline { 2 - 6 } & Yes & No & Yes & No & Category \\
\hline 1 & 54 & 0 & 100 & 0 & Very good \\
2 & 54 & 0 & 100 & 0 & Very good \\
3 & 52 & 2 & 96,30 & 3,70 & Very good \\
4 & 54 & 0 & 100 & 0 & Very good \\
5 & 44 & 10 & 81,48 & 18,52 & Very good \\
6 & 52 & 2 & 96,30 & 3,70 & Very good \\
7 & 54 & 0 & 100 & 0 & Very good \\
8 & 49 & 5 & 90,74 & 9,26 & Very good \\
\hline
\end{tabular}

The average percentage of responses of students as a whole for positive questions was $95.60 \%$, while for negative questions that was equal to $4.40 \%$. So from this percentage, it can be confirmed if the results of the response were very good because they have successfully applied the TPS type cooperative learning model by problem posing strategies to practice creative thinking skills on this acid-base material.

\section{CONCLUSION}

Based on the above assessment, an overview was obtained:

1. The implementation of think-pair-share type (TPS) cooperative learning model with problem posing strategy in this study gets a percentage above $61 \%$ with an average percentage of accomplishment from the first meeting of $91.67 \%$ and $98.60 \%$ for the second meeting which both are included in the excellent category.

2. The activities of relevant students at the first meeting were $94.69 \%$ and that not relevant were $5.31 \%$, whereas when the second meeting the relevant activities were $93.09 \%$ and those that not relevant were $6.91 \%$. Student activities in the criteria were very good because relevant activities was more prominent than those that not relevant.

3. Students' creative thinking skills have increased, with the results of an increase in the posttest shown by an average gain score of $40.74 \%$ in the high category, $44.44 \%$ in medium category, and $14.82 \%$ in low category. Based on the average percentage, it can be said that creative thinking skills have been trained in the medium category.

4. Classical completeness of learning outcomes in the realm of knowledge in the indicators and acid-base $\mathrm{pH}$ lessons obtained a percentage of $88.89 \%$. Learning 
outcomes have increased with moderate $\mathrm{N}$-gain criteria by 13 while for high criteria by 41 . So it can be said that mastery learning has been achieved.

5. Students' responses to the application of think-pair-share type (TPS) cooperative learning with problem posing strategies can be said that the average answers given get a positive response that was equal to $95.60 \%$, while for negative questions that was equal to $4.40 \%$. So from this percentage, the results of students' responses included in the excellent category.

\section{SUGGESTION}

Based on the research results obtained, researchers provide advice including:

1. Creative thinking skills in the originality component need to be trained deeper and repeatedly by the teacher so students can be honed with their creative thinking skills.

2. The application of the learning model implemented requires very time intensive and efficient because the strategies used are quite difficult for students to do if no examples ways of working were provided in advance so that learning and learning objectives can be achieved properly.

3. The teacher first ensures that students understand the concepts that have been taught and learned so then they can work on the questions in the worksheet easily.

\section{REFERENCES}

Abidin, Akhmal A., Siti Masitoh, dan Bachtiar S. B. 2019. Cooperative Learning: Method For Improving Students' Motivation of Post Earthquake In Junior High School of East Lombok. International Journal of Education and Research, vol. 7, No. 8: 41-48.

Alghafri, A. S. R., \& Ismail, H. N. B. 2014. The Effect of Integrating Creative and Critical Thinking on Schools Students' Thinking. International Journal of Social Science and Humanity, 4(6), 518-525.

Anderson, L.W. dan Krathwohl, D.R. 2001. A Taxonomy for Learning, Teaching, and Assesing. New York: Longman Publishing.

Apino, E., \& Retnawati, H. 2017. Developing Instructional Design to Improve Mathematical Higher Order Thinking Skills of Studentas. In Journal of Physics Conference Series. IOP Publishing. Vol. 812, No. 1, p. 0121000. 
Arends, Richard I. 2013. Learning To Teach: Belajar Untuk Mengajar. Penerjemah Helly Prajitno Soetjipto dan Sri Mulyantini Soetjipto. Edisi Ketujuh. Yogyakarta: Pustaka Pelajar.

Arifin. 2010. Evaluasi Pembelajaran. Bandung: Remaja Rosdakarya.

Arki, Andi K.H., Army Auliah, dan Iwan Dini. 2017. Pengaruh Model Pembelajaran Kooperatif Tipe Think-Pair-Share Untuk Meningkatkan Hasil Belajar Siswa Kelas XI MIPA 2 SMA Negeri 3 Model Takalar (Studi pada Materi Pokok Larutan Asam-Basa). Jurnal Chemical,Vol. 18, No. 2: 71-79.

Emerson, Tisha L.N., Linda English, and KimMarie McGoldrick. 2016. Cooperative Learning and Personality Types. International Review of Economics Education, vol. 2, No. 21: 21-29.

Handayani, Riska D., \& Yuli Yanti. 2017. Pengaruh Model Pembelajaran Kooperatif Tipe Think Pair Share Terhadap Hasil Belajar PKn Siswa Di Kelas IV MI Terpadu Muhammadiyah Sukarame Bandar Lampung. Jurnal Pendidikan dan Pembelajaran Dasar,Vol. 4, No. 2: 107-123.

Hetika, Ida Farida, dan Yeni Priatna Sari. 2017. Think Pair Share (TPS) as Method to Improve Student's Learning Motivation and Learning Achievement. Dinamika Pendidikan 12 (2): $125-135$.

Irwansyah, Mukhammad., I Ketut Muhardika., dan Bambang Supriadi. 2016. Penerapan Model Pembelajaran Kooperatif Tipe Think Pair Share (TPS) Disertai Metode Praktikum Untuk Meningkatkan Aktivitas Dan Hasil Belajar Fisika Siswa Kelas XI IPA 3 MAN 1 Jember. Jurnal Pembelajaran Fisika. Vol. 4, No.4, hal: 371-376.

Jannah, Nur H., \& Firman. 2019. Model Pembelajaran Kooperatif Tipe Think Pair Share, Aktivitas Dan Hasil Belajar Peserta Didik. (online) (https://www.researchgate.net/publication/330158438) diakses pada 11 Mei 2020 pukul 10.25 WIB.

Kemendikbud. 2016. Silabus Mata Pelajaran Sekolah Menengah Atas/Madrasah Aliyah (SMA/MA). Jakarta: Kemendikbud.

La Moma. 2015. Pengembangan Instrumen Kemampuan Berpikir Kreatif Matematis Untuk Siswa SMP. Jurnal Matematika Dan Pendidikan Matematika,Vol. 4, No. 1: 27-41.

Lie, Anita. 2007. Cooperative Learning, Mempraktikkan Cooperative Learning di RuangRuang Kelas. Jakarta: PT. Gramedia.

Marliani, Novi. 2015. Peningkatan Kemampuan Berpikir Kreatif Matematis Siswa Melalui Model Pembelajaran Missouri Mathematics Project (MMP). Jurnal Formatif 5(1): 14-25. 
Mu'minin, Siti Kholil Fatkhul dan Utiya Azizah. 2014. Keterampilan Metakognitif Siswa Melalui Model Pembelajaran Inkuiri Pada Materi Asam Basa Di SMAN 1 Pacet Kelas XI. UNESA Journal of Chemical Education, vol. 3, No. 02, pp.67-74.

Muharwati, Titis Indah. 2014. Hubungan Sense Of Humor Dengan Kreativitas Pada Siswa Kelas XI MA Negeri https://www.google.com/url?sa=t\&source=web\&rct=j\&url=http://etheses.uinmalang.ac.id/743/1/10410056\%2520Pendahuluan.pdf\%ved $=2$ ahUKEwjlpag3KnmAhUBfSsKHfPqCUkQFjAAegQIAxAC\&usg=AOvVaw3_4Uf-hovivlcxS5AKaeTv.

Munandar, Utami. 2009. Pengembangan Kreativitas Anak Berbakat. Jakarta: Rineka Cipta.

Murtafiah, Wasilatul. 2017. Profil Kemampuan Berpikir Kreatif Mahasiswa Dalam Mengajukan Masalah Persamaan Diferensial. Jurnal Ilmiah Pendidikan Matematika, vol. 5, No. 2, hal: 73-81.

Nurhasnawati. 2004. Strategi Pengajaran Mikro. Pekanbaru: Fakultas.

Panjaitan, Agustina H., \& Edy Surya. 2017. Creative Thinking (Berpikir Kreatif) Dalam Pembelajaran Matematika. (online) (https://www.researchgate.net/publication/321849189) diakses pada 25 April 2020 pukul 20.04 WIB.

Permendikbud. 2018. Peraturan Menteri Pendidikan dan Kebudayaan Republik Indonesia Nomor 37 Tahun 2018. Jakarta: Mendikbud.

Permendikbud Nomor 104 Tahun 2014 Tentang Penilaian Hasil Belajar Oleh Pendidik Pada Pendidikan Dasar dan Pendidikan Menengah.

Restu H. 2018. Pengaruh Model Pembelajaran Problem Posing Terhadap Kemampuan Berpikir Kreatif Matematis Siswa (Studi pada Siswa Kelas VIII SMP Negeri 1 Lumbok Seminung Semester Genap T.P. 2017/2018). Skripsi. Fakultas Keguruan Dan Ilmu Pendidikan. Universitas Lampung: Bandar Lampung.

Riduwan. 2015. Skala Pengukuran Variabel-Variabel Penelitian. Bandung: Alfabeta.

Sanjaya, W. 2013. Strategi Pembelajaran Berorientasi Standar Proses Pendidikan. Jakarta: Kencana Prenadamedia Group.

Sekhah Efiaty. (2011). Metode Presentasi dalam Proses Pembelajaran. http://missevi.wordpress.com/2011/08/20/metode-presentasi-dalam-proses-pembelajaran/. diakses pada 19 Maret 2020 jam 10.00 WIB

Sengul, Sare dan Yasemin Katranci. 2015. The Analysis Of The Problems Posed By Prospective Mathematics Teachers About 'Ratio and Proportion' Subject. Procedia Social and Behavioral Sciences 174: 1364-1370. 
Siswono, Tatag Yuli Eko. 2004. Mendorong Berpikir Kreatif Siswa Melalui Pengajuan Masalah (Problem Posing). Makalah Disampaikan Pada Konferensi Nasional Matematika XII, Universitas Udayana, Denpasar, Bali. 74-87.

Sitohang, Irene L dan Sahat Saragih. 2018. Pengaruh Pendekatan Pembelajaran Problem Posing Terhadap Kemampuan Pemahaman Konsep Siswa Kelas VIII SMP Swasta Methodist Tanjung Morawa. Jurnal Inspiratif, vol. 4, No. 2: 1-12.

Sriwenda, dkk. 2013. Penerapan Pembelajaran Model Problem Posing Untuk Meningkatkan Kreativitas Dan Prestasi Belajar Siswa Pada Materi Laju Reaksi Kelas XII IPA 5 SMA Negeri 1 Boyolali Tahun Pelajaran 2012/2013. Jurnal Pendidikan Kimia (JPK), Vol. 2, No. 2: 1-6.

Sugiyono. 2018. Metode Penelitian Kuantitatif, Kualitatif, dan R\&D. Bandung: Penerbit Alfabeta.

Sumarya, Fevi. 2020. Meningkatkan Hasil Belajar Peserta Didik Pada Mata Pelajaran IPA Dengan Metode Think Pair Share (TPS) Pada Siswa VIII A Di SMPN 4 Tepung Hilir. Journal of Education and Teaching, vol. 1, No. 1: 37-49.

Suprijono, Agus. 2012. Cooperative Learning. Teori \& Aplikasi Paikem. Yogyakarta: PUSTAKA PELAJAR.

Yogyakarta: PUSTAKA PELAJAR.

. 2016. Cooperative Learning. Teori \& Aplikasi Paikem.

Suriasa. 2018. Penerapan Model Pembelajaran Problem Posing Menggunakan LKS Berbasis Scientific Approach Untuk Meningkatkan Keterampilan Berpikir Kritis Siswa. Berkala Ilmiah Pendidikan Fisika,Vol. 6, No. 2: 190-204.

Trian M. 2016. Strategi Pembelajaran Musik Pada Kursus Piano Tingkat Pre Beginner 1 Di Elfa Music School Kopo Bandung (Studi Kasus Pada Pengajar Piano Bapak Dicky Dwi Lesmana). Skripsi. Fakultas Ilmu Seni Dan Sastra. Universitas Pasundan: Bandung.

Veldman, dkk. 2020. Young children working together. Cooperative learning effects on groupwork of children in Grade 1 of primary education. Learning and Instruction. Netherlands Journal. 67:101308.

Zuya, Habila. 2017. The Benefits of Problem Posing In The Learning of Mathematics: A Systematic Review. Internasional Journal of Advanced Research. Vol. 5. No. 3: 853-860. 